\title{
INDUCTION OF OVULATION BY PREGN-5-ENE-3,20- DIONE AND PROGESTERONE IN IMMATURE RATS TREATED WITH PMSG AND PHENOBARBITAL
}

\author{
B. N. SRIDHARAN, R. K. MEYER AND H. J. KARAVOLAS \\ Departments of Zoology and Physiological Chemistry, \\ Endocrinology-Reproductive Physiology Program, University of Wisconsin, \\ Madison, Wisconsin 53706, U.S.A.
}

(Received 10th July 1973)

Summary. Progesterone and pregn-5-ene-3,20-dione, the proposed intermediate between pregnenolone and progesterone in the rat ovary, were able to overcome the phenobarbital (PB)-induced block of ovulation in the PMSG-primed immature rats when given $3 \frac{1}{2} \mathrm{hr}$ after PB.

Pregnenolone failed to cause ovulation in any of the animals treated with phenobarbital, providing support for the hypothesis that the ovulation-inhibiting action of $\mathrm{PB}$ may be due in part to its inhibitory action on the step in steroidogenesis between pregnenolone and progesterone.

The principal metabolites of progesterone in the hypothalamus and uterus, 5 $\alpha$-pregnane-3,20-dione and $3 \alpha$-hydroxy-5 $\alpha$-pregnan-20-one, were not able to overcome the PB-induced block of ovulation. These results suggest that the action of progesterone in overcoming the PBinduced block of ovulation is not because of its transformation to these two compounds.

\section{INTRODUCTION}

Ovulation in the rat can be prevented by administration of neuropharmacological agents such as phenobarbital (PB) to adult cyclic rats (Everett \& Sawyer, 1950 ) and to immature rats primed with PMSG (Strauss \& Meyer, 1962a; Zarrow \& Brown-Grant, 1964; Ying \& Meyer, 1969a). The animals are treated with PB before the so-called 'critical period' during which time ovulating hormone reaches the optimum blood level for ovulation (Everett, Sawyer \& Markee, 1949). This inhibition of ovulation by barbiturates is explained on the basis of an action at the neural level blocking the spontaneous surge of ovulating hormone (Zeilmaker \& Moll, 1967). Recently, however, evidence was presented for a PB-induced interference with certain steps in steroidogenesis. Meyer, Karavolas, Klausing \& Norgard (1971) reported a rise in blood pregnenolone and a concomitant decrease in blood progesterone during PB-induced block of ovulation. Further support came from observations that ovaries from these 
PB-treated rats have an impaired ability to convert pregnenolone to progesterone when $\left[{ }^{14} \mathrm{C}\right]$ pregnenolone or $\left[{ }^{14} \mathrm{C}\right]$ cholesterol were utilized as substrates (Karavolas, Gupta \& Meyer, 1972; Gupta \& Karavolas, 1973). In the latter experiments, Gupta \& Karavolas (1973) also showed that, in the rat ovary, the first step in the conversion of pregnenolone to progesterone is $3 \beta$-dehydrogenation to give pregn-5-ene-3,20-dione followed by the $\Delta^{4-5}$-isomerization resulting in progesterone, similar to the enzymatic sequence shown in other species (Cheatum \& Warren, 1960; Ewald, Werbin \& Chaikoff, 1964; Cheatum, Douville \& Warren, 1967).

As administration of progesterone overcame the block of ovulation induced by phenobarbital, it was of interest to determine the ability of related steroids to overcome the PB-induced block of ovulation. This report describes the results obtained when pregnenolone, pregn-5-ene-3,20-dione, progesterone and related steroids were administered after the ovulation was blocked by PB.

\section{MATERIALS AND METHODS}

Rats, 26 days old and weighing 65 to $70 \mathrm{~g}$, were received from the Holtzman Co., Madison, Wisconsin. Between 09.00 and 10.00 hours (CST) 4 days later (Day 30), 8 i.u. PMSG ('Equinex', Ayerst, Chicago) in $0.5 \mathrm{ml}$ physiological saline were injected subcutaneously. In 95 to $100 \%$ of the animals this procedure consistently caused ovulation of seven to ten ova on the morning of Day 33 (Strauss \& Meyer, 1962a,b). If $10 \mathrm{mg}$ PB in $0.25 \mathrm{ml}$ distilled water were given subcutaneously on Day 32 at 10.00 hours, this block of ovulation occurred in all the treated animals.

Steroids were dissolved or suspended in corn oil U.S.P. (Magnus, Maybee and Reynard Inc., New York) and were injected subcutaneously at 13.30 hours on Day 32 in the dosages given in the tables. (Progesterone, pregnenolone and $5 \alpha$-pregnane-3,20-dione were obtained from the Sigma Chemical Co., St Louis; pregn-5-ene-3,20-dione from Steraloids Inc., New York; and $3 \alpha$ hydroxy-5 $\alpha$-pregnan-20-one from Ikapharm, Ramat-Gan, Israel.) All the steroids had been checked for purity using thin-layer and gas chromatography (Karavolas \& Herf, 1971; Karavolas et al., 1972; Gupta \& Karavolas, 1973). Control animals received the same volumes of vehicle.

The animals were housed in a room with a temperature of 75 to $80^{\circ} \mathrm{F}$ and allowed free access to Rockland Rat Chow and water. The lights were automatically turned on at 05.00 and off at 19.00 hours (CST).

All animals were killed on Day 33. The oviducts were dissected and gently compressed between two microscope slides and the ova were counted under magnification. The data were analysed using the $\chi^{2}$ test.

\section{RESULTS}

Ovulation was induced in all the animals following injection of 8 i.u. PMSG, and an average of seven to ten ova were found on the morning of Day 33 (Tables 1 to 3). Administration of PB at 10.00 or 13.30 hours on Day 32 blocked ovulation in all the treated animals (Table 1) but was ineffective when given after the critical period at 17.00 hours. 
Table 1. Effect of pregnenolone, progesterone and $5 \alpha-$ pregnane-3,20-dione on phenobarbital-induced block of ovulation in immature rats primed with PMSG

\begin{tabular}{|c|c|c|c|}
\hline Treatment* & $\begin{array}{l}\text { No. of rats } \\
\text { ovulating }\end{array}$ & Ovulation & $\begin{array}{c}\text { Average no. of ova } \pm S . E . / \\
\text { ovulating rat }\end{array}$ \\
\hline Controls & $\begin{array}{l}5 / 5 \\
3 / 3\end{array}$ & $\begin{array}{l}100 \\
100\end{array}$ & $\begin{array}{l}8 \cdot 2 \pm 1 \cdot 2 \\
7 \cdot 3 \pm 0 \cdot 9\end{array}$ \\
\hline $\begin{array}{r}\text { Phenobarbital } \\
10.00 \text { hours } \\
13.30 \text { hours } \\
17.00 \text { hours }\end{array}$ & $\begin{array}{l}0 / 4 \\
0 / 4 \\
3 / 3\end{array}$ & $\begin{array}{r}0 \\
0 \\
100\end{array}$ & $\frac{\bar{E}}{9 \cdot 0 \pm 2 \cdot 5}$ \\
\hline $\begin{array}{l}\text { Progesterone } \dagger \\
0.5 \mathrm{mg} \\
1.5 \mathrm{mg}\end{array}$ & $\begin{array}{l}3 / 3 \\
5 / 5\end{array}$ & $\begin{array}{l}100 \\
100\end{array}$ & $\begin{array}{l}8.7 \pm 1.5 \\
9 \cdot 6 \pm 0.4\end{array}$ \\
\hline $\begin{array}{l}\text { Pregnenolone } \uparrow \\
1.5 \mathrm{mg}\end{array}$ & $0 / 5$ & 0 & - \\
\hline $\begin{array}{l}\text { 5 } \alpha \text {-Pregnane- } \\
3,20 \text {-dione } \dagger \\
0.5 \mathrm{mg} \\
2.0 \mathrm{mg}\end{array}$ & $\begin{array}{l}1 / 5 \\
0 / 4\end{array}$ & $\begin{array}{r}20 \\
0\end{array}$ & 3 \\
\hline
\end{tabular}

* All animals were treated with 8 i.u. PMSG at 09.30 hours on Day 30 of age and were killed on Day 33. Controls were not given any further treatment.

$\dagger$ Steroids were injected on Day 32 at 13.30 hours, $3 \frac{1}{2} \mathrm{hr}$ after phenobarbital.

Pregnenolone at a dose of $1.5 \mathrm{mg} /$ animal and $3 \alpha$-hydroxy-5 $\alpha$-pregnan-20-one in doses of 0.5 or $1.5 \mathrm{mg}$ /animal were unable to overcome the PB block. Treatment with $5 \alpha$-pregnane-3,20-dione was also ineffective in reversing the block when given $3 \frac{1}{2}$ hr before or after PB (Tables 1 and 2). By contrast, progesterone in doses of 0.5 or $1.5 \mathrm{mg}$ prevented the block of ovulation in all the treated animals. As shown in Table 3 , the $\Delta^{5}$-isomer of progesterone, pregn-5ene-3,20-dione, did overcome the PB block. This steroid appears to be very consistent in its ability to reverse the $\mathrm{PB}$ effect in immature rats primed with

Table 2. Effect of progesterone, $3 \alpha$-hydroxy- $5 \alpha$-pregnan-20-one and $5 \alpha$-pregnane-3,20-dione in preventing block of ovulation by phenobarbital in immature rats primed with PMSG

\begin{tabular}{|c|c|c|c|}
\hline Treatment* & $\begin{array}{l}\text { No. of rats } \\
\text { ovulating }\end{array}$ & $\stackrel{\%}{\%}$ & $\begin{array}{c}\text { Average no. of ova } \pm S . E . / \\
\text { ovulating rat }\end{array}$ \\
\hline Controls & $4 / 4$ & 100 & $7.5 \pm 0.9$ \\
\hline $\begin{array}{l}\text { Progesterone } \\
0.5 \mathrm{mg}\end{array}$ & $2 / 2$ & 100 & $7 \cdot 0 \pm 4 \cdot 0$ \\
\hline $\begin{array}{l}3 \alpha-\text { Hydroxy- } 5 \alpha \text {-pregnan-20-one } \\
0.5 \mathrm{mg} \\
1.5 \mathrm{mg}\end{array}$ & $\begin{array}{l}0 / 5 \\
0 / 5\end{array}$ & $\begin{array}{l}0 \\
0\end{array}$ & 二 \\
\hline $\begin{array}{l}5 \alpha-\text { Pregnane-3,20-dione } \\
0.2 \mathrm{mg} \\
0.5 \mathrm{mg} \\
1.5 \mathrm{mg} \\
3.0 \mathrm{mg}\end{array}$ & $\begin{array}{l}0 / 5 \\
0 / 5 \\
0 / 5 \\
0 / 5\end{array}$ & $\begin{array}{l}0 \\
0 \\
0 \\
0\end{array}$ & $\begin{array}{l}\overline{-} \\
\overline{-}\end{array}$ \\
\hline
\end{tabular}

* Steroids were given at 10.00 hours and phenobarbital at 13.30 hours. 
PMSG. In repeated experiments (Table 3 ), this compound exhibited a potency equal to progesterone in reversing the PB-induced block of ovulation $\left(\chi^{2}=\right.$ $1 \cdot 85, P>0 \cdot 05)$.

Table 3. Comparison of the effects of progesterone and pregn-5-ene-3,20-dione in overcoming phenobarbital-induced block of ovulation in rats primed with PMSG

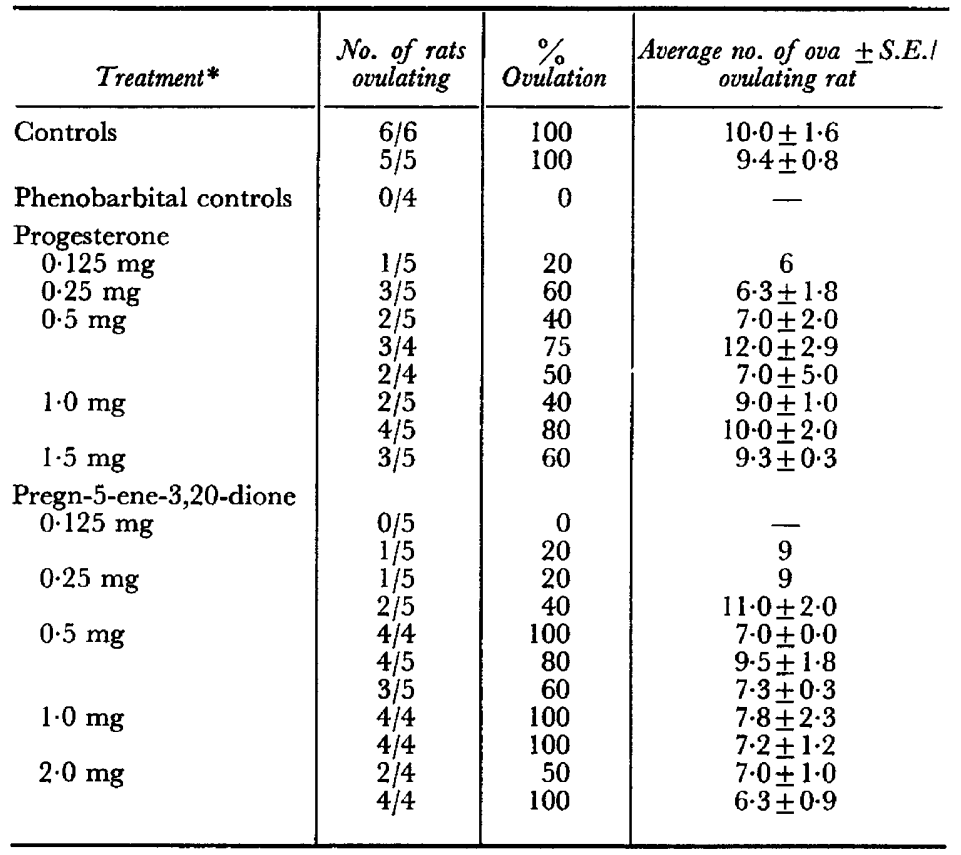

* Phenobarbital was given at 10.00 hours and the steroids at 13.30 hours.

\section{DISCUSSION}

The data in Tables 1, 2 and 3 indicate that progesterone was able to overcome the PB-induced block of ovulation, and are in agreement with the results of Ying \& Meyer (1969a) and Meyer et al. (1971). The ability shown by pregn5-ene-3,20-dione, which has been tested for the first time, to overcome the PB-induced inhibition of ovulation is significant in view of the recent work by Gupta \& Karavolas (1973) who reported that pregn-5-ene-3,20-dione is probably the intermediate steroid between pregnenolone and progesterone in the PMSG-treated immature rat ovary and that treatment of the animals with PB inhibits the dehydrogenation of pregnenolone to pregn-5-ene-3,20dione. The ability of pregn-5-ene-3,20-dione to overcome the PB block of ovulation could mean that the isomerase activity is not appreciably affected by PB treatment. It is also possible, however, that the compound need not be converted into progesterone for its action and may overcome the PB effect by direct action.

None of the animals treated with pregnenolone ovulated but progesterone 
was able to overcome the PB-induced block of ovulation. A decrease in progesterone with a concurrent increase in pregnenolone in the plasma of rats treated with PB led Meyer et al. (1971) to postulate that the ability of this drug to inhibit ovulation may be due in part to the inhibition of the step in steroidogenesis between pregnenolone and progesterone. These findings were supported and extended by the work of Karavolas et al. (1972) and Gupta \& Karavolas (1973). Karavolas et al. (1972) reported that if ovaries were treated with PB and then incubated with $\left[{ }^{14} \mathrm{C}\right]$ cholesterol, they showed an increased accumulation of pregnenolone and $17 \alpha$-hydroxypregnenolone and a decreased accumulation of progesterone compared to ovaries which were not treated with $\mathrm{PB}$. The study of Gupta \& Karavolas (1973) indicated that conversion of $\left[{ }^{14} \mathrm{C}\right]$ pregnenolone to $17 \alpha$-hydroxypregnenolone was not affected by $\mathrm{PB}$ while conversion into progesterone, pregn-5-ene-3,20-dione and 17 $\alpha$-hydroxyprogesterone was affected. If interference of $\mathrm{PB}$ with the conversion of pregnenolone into progesterone is related to the inhibition of ovulation, then progesterone should be able to overcome the block of ovulation while pregnenolone should not. Our results support this hypothesis. This is noteworthy as pregnenolone does have a facilitative action on ovulation in immature rats given a nonovulatory dose of PMSG and no PB (Sridharan, Meyer \& Karavolas, 1974).

Metabolic studies of progesterone in the hypothalamus as well as in the uterus have been utilized to elucidate the mode of action and the modulation of feed-back controls. Karavolas \& Herf (1971) studied the metabolism in vitro of $\left[{ }^{3} \mathrm{H}\right]$ progesterone by the medial basal hypothalamus of pro-oestrous female rats and found that progesterone was converted mainly into $5 \alpha$-pregnane3,20-dione. This was interesting as the compound is a product of the action of $5 \alpha$-reductase on progesterone and might be a key metabolic step, especially when considered in the light of the rôle of testosterone- $5 \alpha$-reductase in converting testosterone to the very potent androgen, dihydrotestosterone (Bruchovsky \& Wilson, 1968a, b; Liao \& Fang, 1969). The predominant metabolite of progesterone in the uterine tissue is also $5 \alpha$-pregnane-3,20-dione (Wiest, 1963; Armstrong \& King, 1971). In the present study, however, $5 \alpha$-pregnane3,20-dione was unable to overcome the PB effect in doses up to $3 \mathrm{mg}$ (Tables 1 and 2). Experiments in this laboratory, however, have shown that $5 \alpha-$ pregnane-3,20-dione does have a facilitative action in 22-day-old immature rats given a non-ovulatory dose of 12 i.u. PMSG.

The progesterone metabolite, $3 \alpha$-hydroxy- $5 \alpha$-pregnane-20-one, has been found in the nuclear fraction of the hypothalamus of pro-oestrous rats (Cheng \& Karavolas, 1973) and in the uterine tissue (Howard \& Wiest, 1972). In doses of up to $1.5 \mathrm{mg}$ this compound also failed to show any reversal of the inhibitory action of $\mathrm{PB}$ and when tested in 22-day-old rats, this compound, unlike pregnenolone and $5 \alpha$-pregnane-3,20-dione, did not exhibit a facilitatory effect on ovulation. These results suggest that the action of progesterone in overcoming the $\mathrm{PB}$ block of ovulation is not due to it being transformed into either of these metabolites.

In the present experiments, an interval of $3 \frac{1}{2} \mathrm{hr}$ elapsed between the time of administration of $\mathrm{PB}$ and the effective doses of progesterone but when pro- 
gesterone was administered simultaneously with $\mathrm{PB}$, the ovulatory effects in the immature rats (and also in adult rats-Redmond, 1968) were considerably reduced. In hamsters, however, Greenwald (1971) showed that simultaneous injection of progesterone with lower doses of $\mathrm{PB}$ (which did not cause behavioural depression) restored ovulation in many of the treated animals. The effects produced by $\mathrm{PB}$ and progesterone are therefore to be interpreted with caution as the time and dose of injection in relation to the stage of the oestrous cycle and lighting regimen, and the presence of other steroids can all influence the results (Strauss, 1964; Ying \& Meyer, 1969b; Harris \& Naftolin, 1970). Although the present study deals with the effects of progestational steroids, the profound influence of oestrogen in the sequence of events leading to ovulation is known to be equally important (Neill, Freeman \& Tillson, 1971).

While the blocking action of barbiturates on the central nervous system and on the pro-oestrous LH surge is known (Everett, 1961), the mechanism of action of progesterone in overcoming the effect of $\mathrm{PB}$ is not clear. On the basis of their work on electrical stimulation of the hypothalamus, Zeilmaker \& Moll (1967) postulated that progesterone and pentobarbitone both act directly on the hypothalamus and that pentobarbitone acts at a site which is closer to the median eminence. Using radioimmunoassay, Caligaris, Astrada \& Taleisnik (1971) have demonstrated release of LH within 3 to $5 \mathrm{hr}$ of the injection of progesterone in ovariectomized rats primed with oestrogen. The elegant experiments of Sawyer and his colleagues (Sawyer, Critchlow \& Barraclough, 1955; Kawakami \& Sawyer, 1959, 1967) showed that neuropharmacological drugs as well as progesterone were able to induce electrical changes in the central nervous system. Pentobarbital raised the threshold to electric arousal of the reticular formation in the rat. In ovariectomized rabbits primed with oestrogen, the progestins evolved biphasic threshold changes. Kobayashi \& Miyake (1971) suggested that, in facilitating ovulation, progesterone is probably affecting not only the hypothalamus but higher centres also.

Direct effects of progesterone on the ovary are usually excluded and the lack of effect of progesterone on the ovarian response to gonadotrophins in hypophysectomized animals is cited as evidence (Krahenbuhl \& Desaulles, 1964; France \& Pincus, 1964; Callantine \& Humphrey, 1965; Smith \& Bradbury, 1966). Redmond (1968), however, produced evidence to show that progesterone can alter the ovulatory response to exogenous gonadotrophins, and Labhsetwar (1971) reported that administration of up to five times the threshold dose of $\mathrm{LH}$ failed to induce the level of ovulation in progesteronetreated rats which normally occurs in oestrous rats, implying a direct effect of progesterone on the ovary.

The importance of optimal steroid environment in relation to the neural activation of the adenohypophysis before the release of ovulating hormone is well known (Ying \& Meyer, 1969a). The known alteration of steroidogenesis by PB treatment in the rat has led to the suggestion (Meyer et al., 1971) that the failure of ovulation may be due in part to PB interfering with the development of the optimal steroid environment. The drug may also alter thresholds within the hypothalamus to intrinsic neural stimuli either directly or indirectly through an altered steroid environment. The inhibition of ovulation after PB 
may thus be a result of multiplicity of sites of action of the neuropharmacological drug.

\section{ACKNOWLEDGMENTS}

This investigation was supported by Ford Foundation Grant No. 630-0505A and one of us (H.J.K.) is a Research Career Development Awardee NICHD No 1 . $\mathrm{K}_{4}$-HD-70,006-01.

\section{REFERENGES}

Armstrong, D. T. \& King, E. R. (1971) Uterine progesterone metabolism and progestational response: effects of estrogens and prolactin. Endocrinology, 89, 191.

BRUchovsky, N. \& WiLson, J. D. (1968a) The conversion of testosterone to $5 \alpha$-androstan-17 $\beta$-ol-3-one by rat prostate in vivo and in vitro. F. biol. Chem. 243, 2012.

Bruchovsky, N. \& Wilson, J. D. (1968b) The intranuclear binding of testosterone and $5 \alpha$-androstan$17 \beta$-ol-3-one by rat prostate. F. biol. Chem. 243, 5953.

Galigaris, L., Astrada, J. J. \& Taleisnix, S. (1971) Biphasic effect of progesterone on the release of gonadotrophin in rats. Endocrinology, 89, 331.

Callantine, M. R. \& Humphrey, R. P. (1965) Effect of progesterone on pituitary and ovarian responsiveness to placental gonadotrophins. Endocrinology, 77, 921.

Cheatum, S. G., Douville, A. W. \& Warren, J. G. (1967) Site specificity of bovine adrenal $3 \beta$ hydroxysteroid dehydrogenase and $\Delta^{5}$-3-ketosteroid isomerase. Biochim. biophys. Acta, 137, 172.

Gheatum, S. G. \& Warren, J. C. (1960) Purification and properties of $3 \beta$-hydroxysteroid dehydrogenase and $\Delta^{5}$-3-ketosteroid isomerase from bovine corpora lutea. Biochim. biophys. Acta, 122, 1.

Gheng, Y. J. \& Karavolas, H. J. (1973) Conversion of progesterone to $5 \alpha$-pregnane-3,20-dione and $3 \alpha$-hydroxy-5 $\alpha$-pregnan-20-one by rat medial basal hypothalami and the effects of estradiol and stage of estrous cycle on the conversion. Endocrinology, 93, 1157.

EVERETT, J. W. (1961) The mammalian female reproductive cycle and its controlling mechanisms. In Sex and Internal Secretions, 3rd edn, pp. 497-555. Ed. W. C. Young. Williams and Wilkins, Baltimore.

Everett, J. W. \& SAwYer, C. H. (1950) A 24-hour periodicity in the "LH-release apparatus" of female rats, disclosed by barbiturate sedation. Endocrinology, 47, 198.

Everett, J. W., Sawyer, G. H. \& Markee, J. E. (1949) A neurogenic timing factor in control of the ovulatory discharge of luteinizing hormone in the cyclic rat. Endocrinology, 44, 234.

Ewald, W., Werbin, H. \& Chaikoff, I. L. (1964) Partial separation of beef adrenal $\Delta^{5}$-3-ketosteroid isomerases: androst-5-ene-3,17-dione isomerase and pregn-5-ene-3,20-dione isomerase. Steroids, 4, 759 .

France, E. S. \& Pincus, G. (1964) Biologically active substances affecting gonadotrophin-induced ovulation in immature rats. Endocrinology, 75, 359.

Greenwald, G. S. (1971) Preovulatory changes in ovulating hormone in the cyclic hamster. Endocrinology, 88, 671 .

Gupta, C. \& Karavolas, H. J. (1973) Lowered ovarian conversion of ${ }^{14} \mathrm{C}$-pregnenolone to progesterone and other metabolites during phenobarbital (PB) block of PMS-induced ovulation in immature rats: inhibition of $3 \beta$-hydroxysteroid dehydrogenation. Endocrinology, 92, 117.

Harris, G. W. \& Naftolin, F. (1970) The hypothalamus and control of ovulation. Br. med. Bull. $26,3$.

Howard, P. D. \& Wiest, W. G. (1972) Progesterone metabolism by uterine tissue of pregnant rats. Steroids, 19, 35.

Karavolas, H. J., Gupta, G. \& Meyer, R. K. (1972) Steroid biosynthesis and metabolism during phenobarbital (PB) block of PMS-induced ovulation in immature rats. Endocrinology, 91, 157.

Karavolas, H. J. \& HerF, S. M. (1971) Conversion of progesterone by rat medial basal hypothalamic tissue to $5 \alpha$-pregnane-3,20-dione. Endocrinology, 89, 940.

Kawakami, M., \& SaWYer, C. H. (1959) Neuroendocrine correlates of changes in brain activity thresholds by sex steroids and pituitary hormones. Endocrinology, 65, 652 .

KaWAKami, M. \& SAWYER, C. H. (1967) Effects of sex hormones and antifertility steroids on brain thresholds in the rabbit. Endocrinology, 80, 857.

Krahenbuhl, G. \& Desaultes, P. A. (1964) The action of sex hormones on gonadotrophin-induced ovulation in hypophysectomized prepuberal rats. Acta endocr., Copenh. 47, 457.

Kobayashi, F. \& Mryake, T. (1971) Acute effect of hypothalamic deafferentation on progesteroneinduced ovulating hormone release in rats. Endocr. jap. 18, 395. 
LABHSETWAR, A. P. (1971) Exploration of site(s) of action of progesterone in inhibiting ovulation in rats. Biol. Reprod. 5, 115.

LiAO, S. \& FANG, S. (1969) Receptor-proteins for androgens and the mode of action of androgens on gene transcription in ventral prostate. Vitams Horm. 27, 17.

Meyer, R. K., Karavolas, H. J., Klausing, M. \& Norgard, D. W. (1971) Blood progesterone and pregnenolone levels during phenobarbital (PB) block of PMS-induced ovulation in immature rats. Endocrinology, 88, 983.

Neill, J. P., Freeman, M. E. \& Tillson, S. A. (1971) Control of the proestrus surge of prolactin in luteinizing hormone secretion by estrogens in the rat. Endocrinology, 89, 1448.

REDMond, W. C. (1968) Ovulatory response to brain stimulation or exogenous luteinizing hormone in progesterone-treated rats. Endocrinology, 83, 1013.

Sawyer, C. H., Gritchlow, B. V. \& Barraclough, C. A. (1955) Mechanism of blockade of pituitary activation in the rat by morphine, atropine and barbiturates. Endocrinology, 57, 345.

Smith, B. D. \& Bradbury, J. T. (1966) Influence of progestins on ovarian responses to estrogen and gonadotrophins in immature rats. Endocrinology, 78, 297.

Sridharan, B. N., Meyer, R. K. \& Karavolas, H. J. (1974) Effect of $5 \alpha$-dihydroprogesterone, pregn-5-ene-3,20-dione, pregnenolone and related progestins on ovulation in PMSG-treated immature rats. F. Reprod. Fert. 36, 83.

Strauss, W. F. (1964) Neural timing of ovulation in immature rats treated with gonadotrophin. Ph.D. thesis, University of Wisconsin.

Strauss, W. F. \& Meyer, R. K. (1962a) Neural timing of ovulation in immature rats treated with gonadotrophin. Science, $\mathcal{N}, \Upsilon$. 137, 860 .

Strauss, W. F. \& MEYER, R. K. (1962b) Neural timing of ovulation in immature rats treated with gonadotrophin: effect of light (15 min). Am. Zoologist, 2, 219.

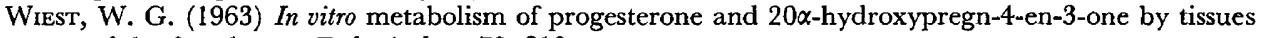
of the female rat. Endocrinology, 73, 310.

YING, S. Y. \& MEYER, R. K. (1969a) Effects of steroids on neuropharmacologic blockade of ovulation in pregnant mare's serum (PMS)-primed immature rats. Endocrinology, 84, 1466.

YING, S. Y. \& MEYeR, R. K. (1969b) Effect of progesterone on induced ovulation in immature rats. 7. Reprod. Fert. $20,279$.

Zarrow, M. X. \& BRown-Grant, K. (1964) Inhibition of ovulation in the gonadotrophin-treated immature rat by chlorpromazine. F. Endocr. 30, 87.

Zemmaker, G. H. \& Moll, J. (1967) Effects of progesterone and pentobarbitone on hypothalamic induction of ovulation in the 5-day cyclic rat. Acta endocr., Copenh. 55, 378. 